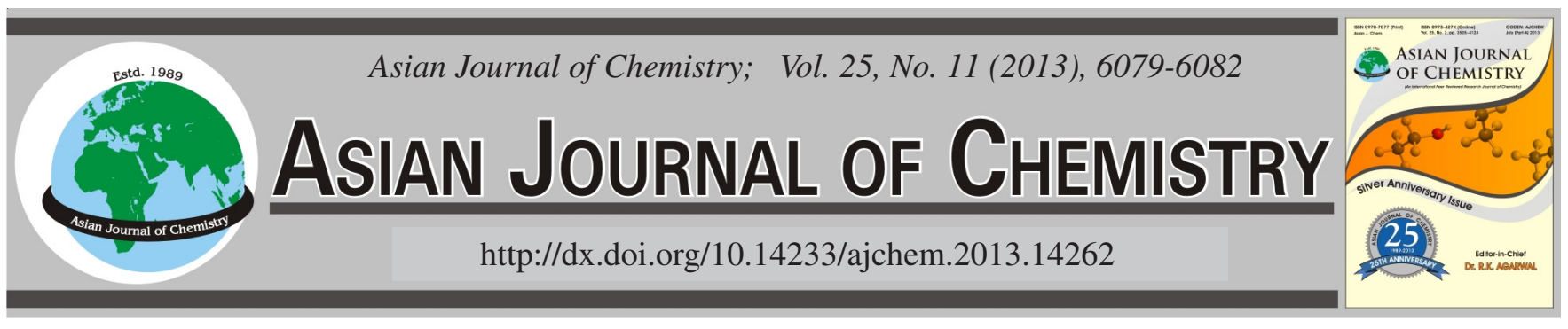

\title{
Synthesis and Crystal Structure of 1-Cyclopropyl-6,7-difluoro-8-methoxy-4-oxo- 1,4-dihydro-3-quinoline carboxylic acid- $\left(\mathrm{O}^{3}, \mathrm{O}^{4}\right)$-bis-(acetate-O)borate
}

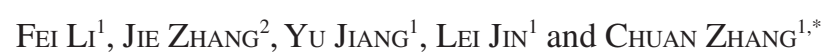

\begin{abstract}
${ }^{1}$ New Drug Research Center, School of Pharmacy, Second Military Medical University, Shanghai 200433, P.R. China
\end{abstract}
${ }^{2}$ The Second Out-Patient Department, National Defence University, Beijing 100039, P.R. China

*Corresponding author: Fax: +86 21 81871359; Tel: +86 21 81871358; E-mail: zhangchuan@ @mmu.edu.cn

\begin{abstract}
The crystal structure of the 1-cyclopropyl-6,7-difluoro-8-methoxy-4-oxo-1,4-dihydro-3-quinoline carboxylic acid- $\left(\mathrm{O}^{3}, \mathrm{O}^{4}\right)$-bis-(acetate$O)$ borate has been determined by single crystal X-ray diffraction method. The crystal belongs to monoclinic with space group $\mathrm{P} 2(1) / \mathrm{n}$, with $\mathrm{a}=16.818(9), \mathrm{b}=6.585(4), \mathrm{c}=18.663(4) \AA, \alpha=90, \beta=107.351(7), \gamma=90^{\circ}, \mathrm{V}=1972.8(18) \AA^{3}, \mathrm{Z}=4, \mathrm{Dx}=1.479 \mathrm{Mg} / \mathrm{m}^{3}, \lambda\left(\mathrm{MoK}_{\alpha}\right)$ $=0.128, \mathrm{~F}(000)=908, \mu\left(\mathrm{MoK}_{\alpha}\right)=0.128 \mathrm{~mm}^{-1}, \mathrm{R}=0.1083$ and $\mathrm{wR}=0.3062$ for 2378 reflections with $\mathrm{I}>2 \sigma(\mathrm{I})$. The two rings of fluoroquinolone and borate ring are almost coplanar with dihedral angles values lower than $2^{\circ}$. The crystal structure is stabilized by intermolecular hydrogen bonds and $\pi$ - $\pi$ stacking interactions.
\end{abstract}

Key Words: Synthesis, Crystal structure, 1-Cyclopropyl-6,7-difluoro-8-methoxy-4-oxo-1,4-dihydro-3-quinoline carboxylic acid$\left(\mathrm{O}^{3}, \mathrm{O}^{4}\right)$-bis-(acetate- $\left.O\right)$ borate.

\section{INTRODUCTION}

Tuberculosis (TB), caused predominantly by M. tuberculosis, is one of the most prevalent infectious diseases known to man. The WHO has estimated that 9.2 million new incident cases in 2006, with approximately 1.7 million individual deaths in the same year and one-third of the world population (around 1.7 billion) is latently infected with M. tuberculosis ${ }^{1-3}$. Gatifloxacin and moxifloxacin (Scheme-I) are drugs in pipeline and having been approved by FDA for the treatment of tuberculosis by the year $2010^{4}$. The preparation of moxifloxacin and gatifloxacin involved the condensation of fluoroquinolone core (Scheme-I) or its ester with the side chain in presence of a base at higher temperature. Due to the low regioselectivity of the reaction, however, the product obtained contains the isomer 6 position impurity (Scheme-I) as the major impurity, which is difficult to separate from the product as this is a position isomer. The fluoroquinolone intermediate as the title compound 1-cyclopropyl-6,7- difluoro-8-methoxy-4-oxo-1,4dihydro-3-quinoline carboxylic acid- $\left(\mathrm{O}^{3}, \mathrm{O}^{4}\right)$-bis-(acetate$O$ )borate (3) which facilitate the nucleophilic substitution of fluoride in position 7 by the side chain rather than the formation of the fluoride in position 6 , thereby preventing the formation of the isomer 6 impurity ${ }^{5-7}$. However, there has been no report on the crystal structure of the title compound 1-cyclopropyl6,7-difluoro-8-methoxy-4-oxo-1,4-dihydro-3-quinoline carboxylic acid- $\left(\mathrm{O}^{3}, \mathrm{O}^{4}\right)$-bis-(acetate-O)borate (3) so far. Herein, we report the synthesis and crystal structure of 1-cyclopropyl6,7-difluoro-8-methoxy-4-oxo-1,4-dihydro-3-quinoline carboxylic acid- $\left(\mathrm{O}^{3}, \mathrm{O}^{4}\right)$-bis-(acetate-O)borate.

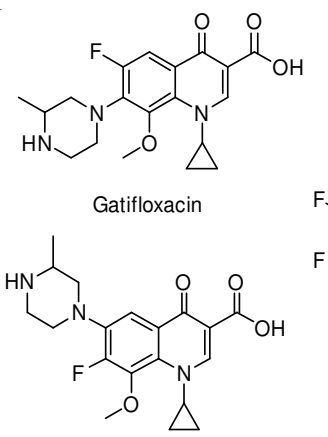

Gatifloxacin isomer

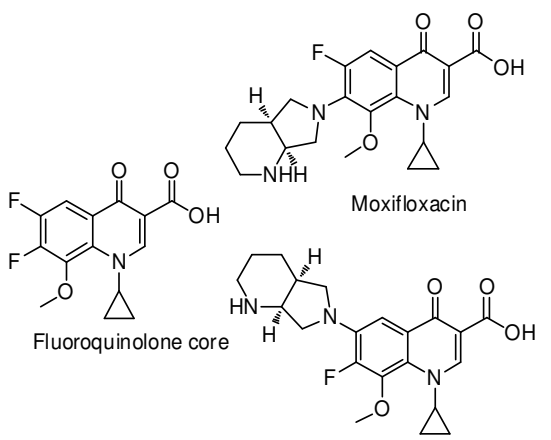

Moxifloxacin isomer
Scheme-I: Fluoroquinolone structures and their 6 position isomer

\section{EXPERIMENTAL}

The melting point was determined on a Yamato MP-21 meltingpoint apparatus and the thermometer was uncorrected. ${ }^{1} \mathrm{H}$ and ${ }^{13} \mathrm{C}$ NMR spectra were measured on a Bruker AC-300P Instrument $(300 \mathrm{MHz})$ with $\mathrm{CDCl}_{3}$ as the solvent. ESI mass spectra were performed on an API-3000 LC-MS spectrometer. The single-crystal structure was determined on a Rigaku Saturn 
<smiles>CCOC(=O)c1cn(C2CC2)c2c(OC)c(F)c(F)cc2c1=O</smiles>

1<smiles>CC(=O)OC(C)=O</smiles>

Boric acid

\section{Acetic anhydride}<smiles>COc1c(F)c(F)cc2c(=O)c(C(=O)O)cn(C3CC3)c12</smiles>

2<smiles>CC(=O)OB(OC(C)=O)OC(C)=O</smiles>

Boron triacetate<smiles>COc1c(F)c(F)cc2c1N(C1CC1)C=C1C(=O)OB(C(C)=O)OC12</smiles>

3
CCD area detector. All the reagents were of analytical reagent grade.

Synthesis and characterization: The 1-cyclopropyl-6,7difluoro-8-methoxy-4-oxo-1,4-dihydro-3-quinoline carboxylic acid- $\left(\mathrm{O}^{3}, \mathrm{O}^{4}\right)$-bis-(acetate-O)borate (3) was prepared according to the following (Scheme-II).

Preparation of compound 2: The mixture of acetic acid $(360 \mathrm{~mL})$, water $(240 \mathrm{~mL})$ was stirred at room temperature and $\mathrm{H}_{2} \mathrm{SO}_{4}(48 \mathrm{~mL})$ was slowly dropwise added. After the temperature was cooled to room temperature, the ethyl 1cyclopropyl-6,7-difluoro-8-methoxy-4-oxo-1,4-dihydroquinoline-3-carboxylate (1) (52 g, $0.16 \mathrm{~mol}$ ) was added slowly under stirring. The reaction mixture was refluxed for $2 \mathrm{~h}$, then cooled to room temperature and the resultant crystalline compound was filtered and washed with water $(500 \mathrm{~mL})$ and dried to afford the compound 1-cyclopropyl-6,7-difluoro-8methoxy-4-oxo-1,4-dihydroquinoline-3-carboxylic acid (2) (45.32 g). Yield: $95.92 \%$; white solid; m.p.188.4-190.2 ${ }^{\circ} \mathrm{C}$. ${ }^{1} \mathrm{H}$ NMR $\left(300 \mathrm{MHz}, \mathrm{CDCl}_{3}\right)$ \%: $9.14(1 \mathrm{H}, \mathrm{s}, 2-\mathrm{H}), 7.71-8.14(1 \mathrm{H}$, $\mathrm{dd}, J=7.8 \mathrm{~Hz}, 9.9 \mathrm{~Hz}, 5-\mathrm{H}), 4.15-4.53$ (1H, m, -NCH-), 3.98 $\left(3 \mathrm{H}, \mathrm{s},-\mathrm{OCH}_{3}\right), 1.12-1.48(4 \mathrm{H}, \mathrm{m}) .{ }^{13} \mathrm{C}$ NMR $(300 \mathrm{MHz}$, $\left.\mathrm{CDCl}_{3}\right) \delta: 175.67,167.61,150.62,146.13,139.54,136.76$, $130.50,123.47,109.35,107.30,60.52,39.94,10.66$. MS (ESI) $m / z$ calc. for $\mathrm{C}_{14} \mathrm{H}_{11} \mathrm{~F}_{2} \mathrm{NO}_{4}$ 295.24, found $[\mathrm{M}+\mathrm{H}]^{+}$296.23.

Synthesis of compound 3: Acetic anhydride (72.2 g, $0.7073 \mathrm{~mol}$ ) was heated to $70{ }^{\circ} \mathrm{C}$ and boric acid $(12.5 \mathrm{~g}, 0.2021$ mol) was slowly added at $70{ }^{\circ} \mathrm{C}$. Then the temperature was raised to $110^{\circ} \mathrm{C}$ for $2 \mathrm{~h}$, followed by cooling to about $50{ }^{\circ} \mathrm{C}$. 1 Cyclopropyl-6,7-difluoro-8-methoxy-4-oxo-1,4-dihydroquinoline3-carboxylic acid (2) (40 g, $0.1354 \mathrm{~mol}$ ) was added under stirring. The reaction mixture temperature was raised to $90^{\circ} \mathrm{C}$ and maintained for $3 \mathrm{~h}$. After the completion of reaction the reaction mixture was cooled to $0{ }^{\circ} \mathrm{C}$, water $(500 \mathrm{~mL})$ was slowly added at $0{ }^{\circ} \mathrm{C}$ and maintained for $1 \mathrm{~h}$. The product was filtered, washed with water $(200 \mathrm{~mL})$ and dried at $45-50{ }^{\circ} \mathrm{C}$ in fluid bed drier to get the compound 1-cyclopropyl-6,7-difluoro8-methoxy-4-oxo-1,4-dihydro-3-quinoline carboxylic acid$\left(\mathrm{O}^{3}, \mathrm{O}^{4}\right)$-bis-(acetate- $O$ )borate 3 (54.6 g). Yield: $95.3 \%$; white solid; m.p. 112-117. ${ }^{1} \mathrm{H}$ NMR (300 MHz, $\left.\mathrm{CDCl}_{3}\right): 9.22(1 \mathrm{H}$, s, 2-H), 8.01-8.38 (1H, dd, $J=8 \mathrm{~Hz}, 10 \mathrm{~Hz}, 5-\mathrm{H}), 4.25-4.40$ $(1 \mathrm{H}, \mathrm{m},-\mathrm{NCH}-), 3.98\left(3 \mathrm{H}, \mathrm{s},-\mathrm{OCH}_{3}\right), 2.04\left(6 \mathrm{H}, \mathrm{s},-\mathrm{OCOCH}_{3}\right)$, 1.14-1.46 (4H, m). ${ }^{13} \mathrm{C}$ NMR (300 MHz, $\left.\mathrm{CDCl}_{3}\right): \delta 190.18$, $169.79,153.55,144.71,139.54,135.85,134.63,123.96$, 107.42, 101.95, 70.29, 60.70, 41.88, 28.73, 9.87. MS(ESI) $m / z$ calc. for $\mathrm{C}_{18} \mathrm{H}_{17} \mathrm{BF}_{2} \mathrm{NO}_{6} 392.14$, found $[\mathrm{M}+\mathrm{H}]^{+}$393.23, $\left[\mathrm{M}-\left(\mathrm{CH}_{3} \mathrm{CO}\right)_{2} \mathrm{O}, 100 \%\right]^{+} 296.26$.

Crystallography studies: The title compound (200 mg) was dissolved in $10 \mathrm{~mL}$ a solvent mixture of $\mathrm{MeOH}$ and water (3:1) and colourless transparent crystals suitable for X-ray analysis grew over a period of two week when the solution was exposed to air at room temperature. The crystal having approximate dimensions of $0.15 \mathrm{~mm} \times 0.12 \mathrm{~mm} \times 0.10 \mathrm{~mm}$ was mounted on the top of a glass fiber in a random orientation. The data were collected by a Bruker SMART 1000 CCD area detector diffractometer equipped with a graphite-monochromatized $\mathrm{MoK}_{\alpha}$ radiation radiation $(\lambda=0.71073 \AA)$ by using a $\phi-\omega$ scan mode at $293 \mathrm{~K}$. A total of 7790 reflections were collected in the range of $1.43<\theta<25.01^{\circ}$, of which 3457 were independent $\left(\mathrm{R}_{\mathrm{int}}=0.1239\right)$ and 2378 were observed with $\mathrm{I}>2 \sigma(\mathrm{I})$.

The data collection and procession were performed with program SMART and SHELXTL ${ }^{8}$. The structure was solved by direct methods and refined by fullmatrix least-squares/ difference Fourier techniques with SHELXS-97 and SHELXL97 programs $^{9}$. All non-hydrogen atoms were refined with anisotropic displacement parameters. After that, all hydrogen atoms were located theoretically and refined with riding model position parameters and fixed isotropic thermal parameters. The final $\mathrm{R}=0.1083, \mathrm{wR}=0.3062\left(\mathrm{w}=1 /\left[\sigma^{2}\left(\mathrm{~F}_{\mathrm{o}}{ }^{2}\right)+(0.2 \mathrm{P})^{2}\right]\right.$, where $\left.\mathrm{P}=\left(\mathrm{F}_{\mathrm{o}}^{2}+2 \mathrm{~F}_{\mathrm{c}}^{2}\right) / 3\right),(\Delta / \sigma)_{\max }=0.004, \mathrm{~S}=1.104,(\Delta \rho)_{\max }$ $=1.032$ and $(\Delta \rho)_{\min }=-0.470 \mathrm{e} / \AA^{-3}$.

\section{RESULTS AND DISCUSSION}

Crystal structure description: The title compound was prepared according to Scheme-II. The ${ }^{1} \mathrm{H}$ NMR, ${ }^{13} \mathrm{C}$ NMR, MS and m.p. for the product are in good agreement with the title compound. In order to confirm the configuration of the product, a single crystal of the title compound was cultured 
for X-ray diffraction analysis. The crystal belongs to monoclinic with space group P2(1)/n. The molecular structure with atomic labeling scheme and perspective view of the crystal packing in a unit cell of the title compound are shown in Figs. 1 and 2, respectively. The selected bond lengths are listed in Table- 1 and the bond angles in Table- 2 .

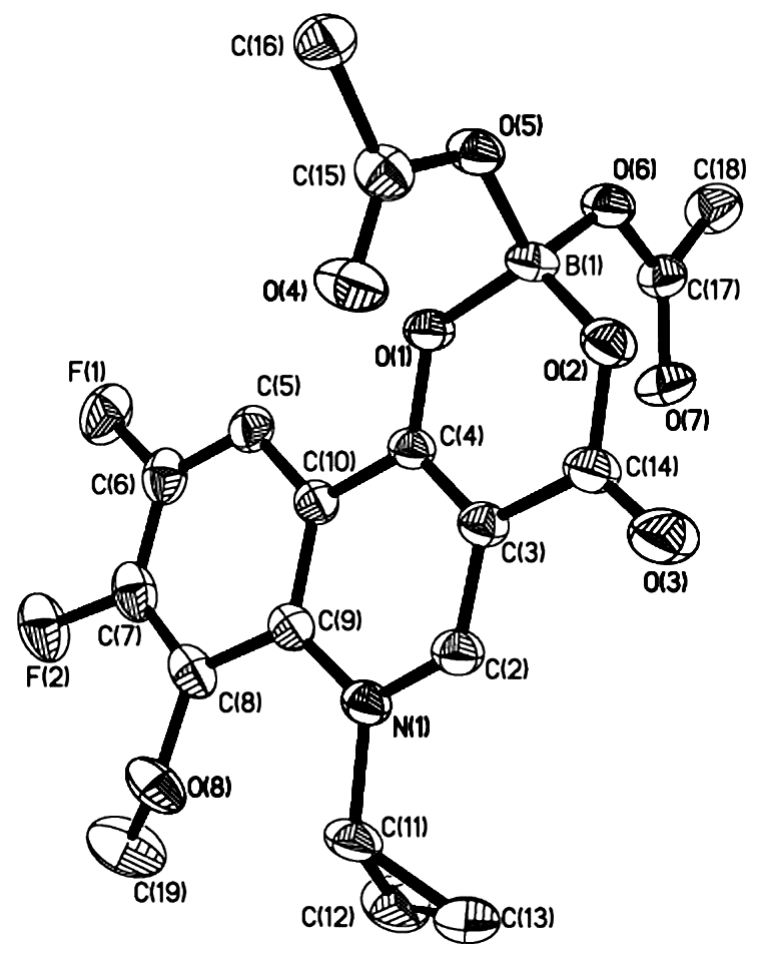

Fig. 1. Molecular structure of the title compound

There are four rings in title compound, an aromatic ring, a cyclopropane ring, a pyridine ring and a borate ring. The two rings of fluoroquinolone and borate ring are almost coplanar with dihedral angles values lower than $2^{\circ}$. The cyclopropane ring makes dihedral angles of $62.53^{\circ}$ with the fluoroquinolone ring system. The molecular structure analysis shows that the conformation of the six-membered borate ring is nearly planar. The bond length of C(4)-C(3) $(1.368(5) \AA)$ is typical for $\mathrm{C}=\mathrm{C}$, so there may be enolization among $\mathrm{O}(1)$ $\mathrm{C}(4)-\mathrm{C}(3)$. The $\mathrm{O}(2)-\mathrm{C}(14)$ coordinated bond length is longer than $\mathrm{C}(3)-\mathrm{O}(14)$ bond length, which is in agreement with the formation of a bond between the anionic carboxylate oxygen atom and boron atom. The 4-oxo group $\mathrm{O}(1)-\mathrm{C}(4)$ and the
$\mathrm{O}(2)-\mathrm{O}(14)$ bond from the 3-carboxylate group, coordinated to boron atom become equivalent, with bond lengths of $1.291(4)$ and 1.311 (4) $\AA$. Because the conjugation system exists in $\mathrm{C}(4)=\mathrm{C}(3)-\mathrm{C}(14)=\mathrm{O}(3)$, the bond length of $\mathrm{C}(3)-\mathrm{C}(14)$ $(1.477(5) \AA)$ is obviously shorter than the standard value of single bond length (1.53 $\AA$ ). The other bond lengths and bond angles in the compound have the expected values. In the solid state of this construction, the crystal structure is stabilized by an efficient three-dimensional network formed by intermolecular hydrogen bonds and $\pi-\pi$ stacking interactions (Fig. 2).

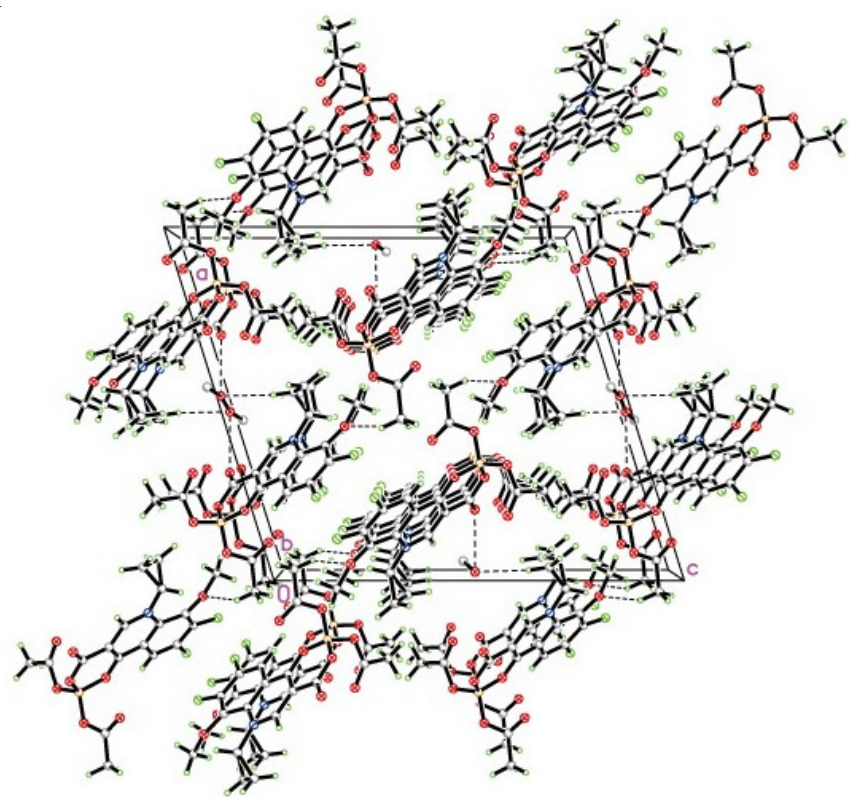

Fig. 2. Crystal packing of the title compound

TABLE-1

SELECTED BOND LENGTHS ( $⿱$ ) FOR THE TITLE COMPOUND

\begin{tabular}{cccccc}
\hline Bond & Length & Bond & Length & Bond & Length \\
\hline $\mathrm{O}(1)-\mathrm{C}(4)$ & $1.291(4)$ & $\mathrm{O}(6)-\mathrm{C}(17)$ & $1.319(5)$ & $\mathrm{C}(10)-\mathrm{C}(5)$ & $1.397(5)$ \\
$\mathrm{O}(1)-\mathrm{B}(1)$ & $1.490(5)$ & $\mathrm{O}(6)-\mathrm{B}(1)$ & $1.435(5)$ & $\mathrm{C}(5)-\mathrm{C}(6)$ & $1.337(5)$ \\
$\mathrm{O}(2)-\mathrm{C}(14)$ & $1.311(4)$ & $\mathrm{O}(8)-\mathrm{C}(8)$ & $1.334(5)$ & $\mathrm{O}(4)-\mathrm{C}(15)$ & $1.202(5)$ \\
$\mathrm{O}(2)-\mathrm{B}(1)$ & $1.445(5)$ & $\mathrm{O}(8)-\mathrm{C}(19)$ & $1.441(5)$ & $\mathrm{C}(8)-\mathrm{C}(7)$ & $1.369(6)$ \\
$\mathrm{O}(5)-\mathrm{C}(15)$ & $1.331(4)$ & $\mathrm{F}(1)-\mathrm{C}(6)$ & $1.336(5)$ & $\mathrm{C}(7)-\mathrm{C}(6)$ & $1.372(6)$ \\
$\mathrm{O}(5)-\mathrm{B}(1)$ & $1.462(5)$ & $\mathrm{F}(2)-\mathrm{C}(7)$ & $1.344(4)$ & $\mathrm{O}(3)-\mathrm{C}(14)$ & $1.194(5)$ \\
$\mathrm{N}(1)-\mathrm{C}(2)$ & $1.325(5)$ & $\mathrm{C}(9)-\mathrm{C}(10)$ & $1.402(5)$ & $\mathrm{C}(15)-\mathrm{C}(16)$ & $1.482(6)$ \\
$\mathrm{N}(1)-\mathrm{C}(9)$ & $1.388(5)$ & $\mathrm{C}(9)-\mathrm{C}(8)$ & $1.421(5)$ & $\mathrm{C}(17)-\mathrm{C}(18)$ & $1.492(6)$ \\
$\mathrm{N}(1)-\mathrm{C}(11)$ & $1.466(5)$ & $\mathrm{C}(3)-\mathrm{C}(2)$ & $1.364(5)$ & $\mathrm{C}(11)-\mathrm{C}(12)$ & $1.470(7)$ \\
$\mathrm{C}(4)-\mathrm{C}(3)$ & $1.368(5)$ & $\mathrm{C}(3)-\mathrm{C}(14)$ & $1.477(5)$ & $\mathrm{C}(11)-\mathrm{C}(13)$ & $1.474(7)$ \\
$\mathrm{C}(4)-\mathrm{C}(10)$ & $1.429(5)$ & $\mathrm{O}(7)-\mathrm{C}(17)$ & $1.198(5)$ & $\mathrm{C}(12)-\mathrm{C}(13)$ & $1.457(9)$ \\
\hline
\end{tabular}

TABLE-2

SELECTED BOND ANGLES $\left({ }^{\circ}\right)$ FOR THE TITLE COMPOUND

\begin{tabular}{|c|c|c|c|c|c|}
\hline Angles & $\left({ }^{\circ}\right)$ & Angles & $\left({ }^{\circ}\right)$ & Angles & $\left({ }^{\circ}\right)$ \\
\hline $\mathrm{C}(3)-\mathrm{C}(4)-\mathrm{C}(10)$ & 119.1(3) & $F(2)-C(7)-C(8)$ & $119.1(4)$ & $\mathrm{O}(6)-\mathrm{B}(1)-\mathrm{O}(2)$ & $111.7(3)$ \\
\hline $\mathrm{C}(17)-\mathrm{O}(6)-\mathrm{B}(1)$ & $119.5(3)$ & $\mathrm{F}(2)-\mathrm{C}(7)-\mathrm{C}(6)$ & $117.5(4)$ & $\mathrm{O}(6)-\mathrm{B}(1)-\mathrm{O}(5)$ & $105.1(3)$ \\
\hline $\mathrm{C}(8)-\mathrm{O}(8)-\mathrm{C}(19)$ & $120.1(4)$ & $\mathrm{C}(8)-\mathrm{C}(7)-\mathrm{C}(6)$ & $123.3(3)$ & $\mathrm{O}(2)-\mathrm{B}(1)-\mathrm{O}(5)$ & $110.1(3)$ \\
\hline $\mathrm{N}(1)-\mathrm{C}(9)-\mathrm{C}(10)$ & $118.7(3)$ & $\mathrm{O}(4)-\mathrm{C}(15)-\mathrm{O}(5)$ & $123.0(4)$ & $\mathrm{O}(6)-\mathrm{B}(1)-\mathrm{O}(1)$ & $108.0(3)$ \\
\hline $\mathrm{N}(1)-\mathrm{C}(9)-\mathrm{C}(8)$ & $123.0(3)$ & $\mathrm{O}(4)-\mathrm{C}(15)-\mathrm{C}(16)$ & $124.5(4)$ & $\mathrm{O}(2)-\mathrm{B}(1)-\mathrm{O}(1)$ & $113.7(3)$ \\
\hline$C(10)-C(9)-C(8)$ & $118.3(4)$ & $\mathrm{O}(5)-\mathrm{C}(15)-\mathrm{C}(16)$ & $112.5(3)$ & $\mathrm{O}(5)-\mathrm{B}(1)-\mathrm{O}(1)$ & $107.9(3)$ \\
\hline $\mathrm{C}(2)-\mathrm{C}(3)-\mathrm{C}(4)$ & $118.9(3)$ & $\mathrm{N}(1)-\mathrm{C}(2)-\mathrm{C}(3)$ & $124.1(3)$ & $\mathrm{N}(1)-\mathrm{C}(11)-\mathrm{C}(12)$ & 119.1(4) \\
\hline $\mathrm{C}(2)-\mathrm{C}(3)-\mathrm{C}(14)$ & $120.4(3)$ & $\mathrm{O}(7)-\mathrm{C}(17)-\mathrm{O}(6)$ & $123.1(3)$ & $N(1)-C(11)-C(13)$ & $119.3(3)$ \\
\hline$C(4)-C(3)-C(14)$ & $120.7(3)$ & $\mathrm{O}(6)-\mathrm{C}(17)-\mathrm{C}(18)$ & $113.1(3)$ & $\mathrm{C}(12)-\mathrm{C}(11)-\mathrm{C}(13)$ & $59.3(4)$ \\
\hline$C(5)-C(10)-C(4)$ & 119.1(3) & $\mathrm{F}(1)-\mathrm{C}(6)-\mathrm{C}(7)$ & $117.9(3)$ & $\mathrm{C}(13)-\mathrm{C}(12)-\mathrm{C}(11)$ & $60.5(4)$ \\
\hline$C(6)-C(5)-C(10)$ & $118.5(4)$ & $\mathrm{O}(3)-\mathrm{C}(14)-\mathrm{O}(2)$ & $121.5(3)$ & $\mathrm{C}(12)-\mathrm{C}(13)-\mathrm{C}(11)$ & $60.2(4)$ \\
\hline $\mathrm{O}(8)-\mathrm{C}(8)-\mathrm{C}(9)$ & $120.6(4)$ & $\mathrm{O}(2)-\mathrm{C}(14)-\mathrm{C}(3)$ & $115.6(3)$ & - & - \\
\hline
\end{tabular}




\section{Conclusion}

In conclusion, the compound 1-cyclopropyl-6,7-difluoro8-methoxy-4-oxo-1,4-dihydro-3-quinoline carboxylic acid$\left(\mathrm{O}^{3}, \mathrm{O}^{4}\right)$-bis-(acetate- $\left.O\right)$ borate, was synthesized and characterized by means of ${ }^{1} \mathrm{H}$ NMR, ${ }^{13} \mathrm{C}$ NMR, MS and X-ray diffraction. The crystal belongs to Monoclinic with space group $\mathrm{P} 2(1) / \mathrm{n}$ and the crystal structure is stabilized by intermolecular hydrogen bonds and $\pi-\pi$ stacking interactions.

Supplementary material: The full crystallographic information has been deposited with the Cambridge crystallographic data center, CCDC No. 887869. Copies of this information may be obtained free of charge from: The Director, CCDC, 12 Union road, Cambridge, CB2 1EZ, UK (fax: +441223-336-033; e-mail: deposit@ccdc.cam.ac. uk or www: http://www.ccdc.cam.ac.uk).

\section{ACKNOWLEDGEMENTS}

This work was supported by the Science and Technology Commission of Shanghai New Drug Fund 2010 (No 10DZ1972300) and the National Key Project for the Investigation of New Drugs (No 2009ZX09301-011).

\section{REFERENCES}

1. C. Dye, S. Scheele, P. Dolin, V. Pathania and M.C. Raviglione, J. Am. Med. Assoc., 282, 677 (1999).

2. A. Kochi, Bull. World Health Organ., 79, 71 (2001).

3. L.S. Feng, M.L. Liu, B. Wang, Y. Chai, X.Q. Hao, S. Meng and H.Y. Guo, Eur. J. Med. Chem., 45, 3407 (2010).

4. P. Senthilkumar, M. Dinakaran, D. Banerjee, R.V. Devakaram, P. Yogeeswari, A. China, V. Nagaraja and D. Srirama, Bioorg. Med. Chem., 16, 2558 (2008).

5. C. Satyanarayana, S.G. Ramanjaneyulu, V.U. Rao and D.V. Narasimharao, US Patent 0264635 (2006)

6. D.R. Rao, R.N. Kankan, S.L. Pathi, R. Puppala, M. Gangrade and S. Kanathala, US Patent 0152229 (2010).

7. A. Castellin, P. Pad ovan, J.G. Liu, Y.B. Zhou and L. Feng, US Patent 0230661 (2011).

8. G.M. Sheldrick, Programs SMART and SHELXTL, Bruker AXS, Inc., Madison, WI, USA (2003).

9. G.M. Sheldrick, SHELXS-97, Program for the Solution of Crystal Structures and SHELXL-97, Program for the Refinement of Crystal Structures, University of Göttingen, Germany (1997). 